\title{
単一光ファイバプローブによる表面張力測定
}

\author{
小澤 佑輔 ${ }^{1}$, 真田 俊之 ${ }^{1}$, 大石 真吾 $^{2}$, 青島 紳一郎 ${ }^{2}$, 齋藤 隆之 ${ }^{1}$ \\ 1静岡大学工学部機械工学科 ( $\bar{T} 432-8561$ 静岡県浜松市中区城北3-5-1)

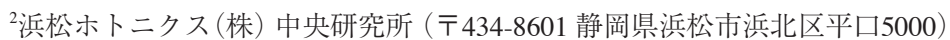

\section{Measurement of Surface Tension Using a Single-Tip Optical Fiber Probe}

\author{
Yusuke OZAWA, ${ }^{1}$ Toshiyuki SANADA, ${ }^{1}$ Shingo OISHI ${ }^{2}$ Shin-ichiro AOSHIMA,${ }^{2}$ and Takayuki SAITO ${ }^{1}$ \\ ${ }^{1}$ Department of Mechanical Engineering, Shizuoka University, 3-5-1 Johoku, Naka-ku Hamamatsu, Shizuoka $432-8561$ \\ ${ }^{2}$ CRL, Hamamatsu Photonics K.K., 5000 Hirakuchi, Hamakita-ku Hamamatsu, Shizuoka 434-8601
}

(Received October 22, 2008)

\begin{abstract}
Optical fiber probing is widely applied to an efficient and reliable measurement for gas-liquid two-phase flows. For the measurement of small- and medium-size bubbles/droplets, we already developed a FourTip Optical fiber Probe (F-TOP) and a Single-Tip Optical fiber Probe (S-TOP). The influences of surface tension on the measurement accuracy are inevitably large due to their being direct-contact probing; i.e. the optical fiber probing is very sensitive to the surface tension. Turning to this disadvantage in bubbles/droplets measurement by the optical probes, this is a prominent characteristic able to be applied to surface tension measurement. In this study, we newly developed a measurement technique for surface tension using the S-TOP on the basis of improvement of the stated above. This measurement is based on the change of the direct proportional relationship between the gradients of the S-TOP signal and gas-liquid interface velocity. One can easily measure surface tension by using this method at a range lower than $60 \mathrm{mN} / \mathrm{m}$. Uncertainty of surface tension measurement using this method is about $5 \%$.
\end{abstract}

Key Words: Surface tension, Single-Tip Optical fiber Probe (S-TOP), Gas-liquid two-phase flow, Wettability

1.はじめに

気液二相流は, 原子炉や熱交換器に代表されるエネル ギー機器ならびに化学反応装置等, 工業分野において広 く見られる複雑流動現象である。これらの装置の高効率 化, 高い安全性を実現するには, 装置内の流動状態を高 精度かつリアルタイムに計測し, 最適な流動状態に保つ 必要がある。これまで, 気液二相流計測においては様々 な手法が考案, 利用されてきた. その中の一つに光ファ イバプローブ法 ${ }^{1-5)}$ がある. 光ファイバプローブ法は, 気相と液相の屈折率差を利用することで気泡・液滴特性 を計測する方法である。これまで，我々は独自に開発し た4点光ファイバプローブ $(\mathrm{F}-\mathrm{TOP})^{6-9)}$ を用いて気液二相 流を対象とした研究を行い, 気泡の三次元運動を高精度 に計測できることを示してきた。 さらに，F-TOP等のマ ルチプローブによる計測が困難な微小気泡・微小液滴の 径・速度の同時計測を可能にする，単一光ファイバプ ローブ $(\mathrm{S}-\mathrm{TOP})^{10,11)}$ を開発した。 しかし, 光ファイバプ ローブ法は接触計測であることから, 表面張力の変化が 計測精度に与える影響 ${ }^{12-14)}$ は大きい。一般的に, 表面張 力の変化は, 気泡・液滴界面の挙動ならびに光ファイバ
プローブのぬれ性を変化させる。 よって，光ファイバプ ローブ計測において，液相の表面張力を把握することは 高精度計測を実現するために重要である。

本研究では上記を光ファイバプローブ計測の負の特性 ではなく，むしろ優れた特性と捉え，S-TOPによる液相 表面張力測定法 ${ }^{15,16)}$ を開発した。従来の表面張力計測方 法は, 力の釣り合い(重力測定法：重力と表面張力との 釣り合い)あるいは力の計測 (力測定法：ワイヤーあるい は薄板に作用する力の計測) から表面張力を算出する方 法である。これに対して, 本提案の表面張力計測手法は, 力の計測を必要とせず, 光の計測のみより表面張力を計 測するものである.

すなわち，S-TOPと気液界面との接触過程における界 面の相対的な運動によるプローブ出力信号の変化特性か ら表面張力を算出・計測する方法である。本研究では, 純水に界面活性剂を添加することで表面張力を任意に変 化させて，種々の条件下で実験を行った，さらに，気液 界面挙動を高速ビデオカメラで可視化し, 接触過程と出 力信号との関係を明らかにした。これらの知見に基づい て, 従来の表面張力計測方法に代わる新たな表面張力計 測法を提示する。 


\section{2. 光ファイバプローブ計測}

\section{1 計測原理}

光ファイバプローブ法は, 気相と液相の屈折率変化に より生じる戻り光量 (プローブ端面で反射される戻り光) の変化を捉え，光量変化の大きさを基に相検出を行うも のである。光ファイバプローブ計測に用いるシステムを Fig. 1に示す. 光源に半導体レーザー(波長635 nm) (1)を 使用し，射出されたレーザー光はビームスプリッター (2)を介して対物レンズ (3) で集光され，光ファイバプ ローブ(4)に入射される。文射光の一部はプローブ端面 において反射した後，同経路を逆進し，ビームスプリッ ターで光路を直角に変える。さらに，偏光板 $(5)$ を介し 光電子増倍管 $(6)$ に入射する. 光電子増倍管で光電変換 された後, $\mathrm{A} / \mathrm{D}$ 変換器(7)を介してPCに取り込まれる。

Fig. 1内の矢印はレーザー光および信号の流れを示した ものである。

光ファイバプローブと気泡との接触による戻り光量 (出力信号)の一例をFig. 2に示す.プローブ端面が液相 に覆われている場合, コア(光ファイバのコア)と液相の 屈折率差が小さくなるために, 光は端面を透過して液相 に抜ける。一方，プローブ端面が気泡に接触すると，コ アと気相の屈折率差は液相時と比べて大きくなり, 端面
(6)

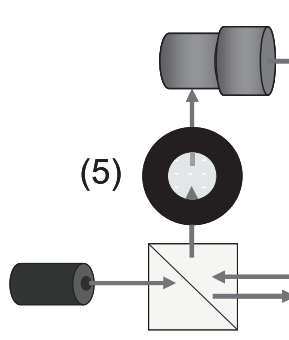

(1)
(2)
(7)

(8)

(1) Laser diode, (2) Beamsplitter, (3) Objective lens, (4) Optical fiber probe, (5) Polarizer, (6) Photo multiplier, (7) A/D converter, (8) PC

Fig. 1 Optics and photoelectric conversion.

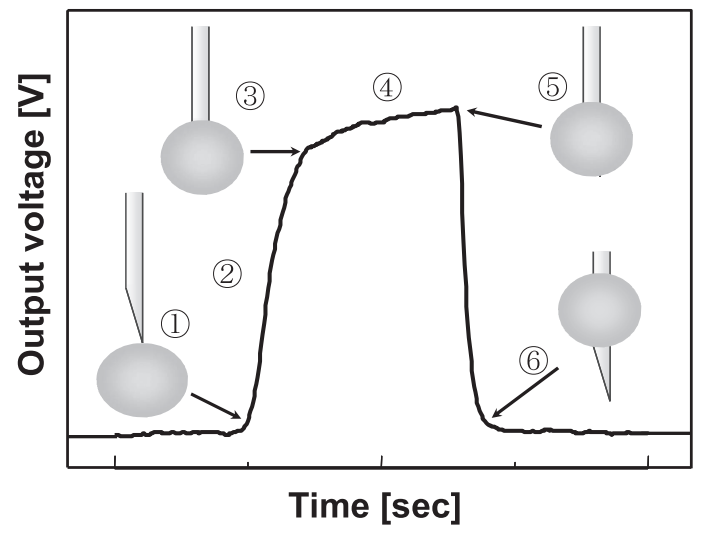

Fig. 2 Typical signal of detecting a bubble.
で光が反射され，戻り光量が増加し始める (Fig. 21). 光 電子増倍管出力の増加開始).さらに, 気泡に覆われる プローブ端面の面積の増加とともに戻り光量が増加して, 光電子増倍管の出力は増加する (Fig. 2(2))。プローブ端 面が完全に気泡に覆われる (Fig. 2(3) と戻り光量の増加 は抑制されて, 光電子増倍管出力はほぼ一定值をとる (Fig. 24)），その後，気泡の離脱に伴い(Fig. 2(5)，端面 は再び液相に覆われるために戻り光量が減少し, 光電子 増倍管出力も減少する (Fig. 26) 。液滴接触過程におい ては, 気泡接触過程とほぼ逆の増減現象を示す.

\subsection{S-TOPによる表面張力計測の原理}

S-TOPの最大の特徵は，端面形状が楔状であることで ある，本計測手法は，端面を楔状にすることで，端面を 通過する気液界面速度によって変化する戻り光量の時間 変化率を利用した速度計測手法である ${ }^{17)}$. S-TOPの先端 構造及び拡大写真をFig. 3に示す。ささに，Fig. 4に端面 を通過する気液界面と出力信号の関係を示す。出力信号 は，端面を覆う気液界面の面積：Sに比例して変化する。 端面は楔状に加工しているため楕円型をしていることか ら，Sは以下の式で与えられる。

$$
S=a b(h-0)+\frac{a b}{2}(\sin 2 h-0)
$$

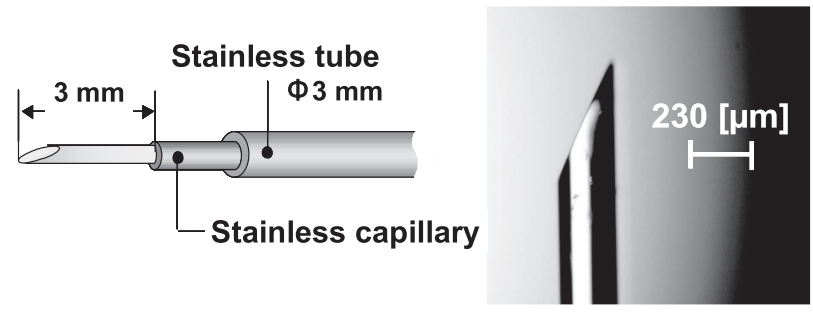

Fig. 3 S-TOP for surface tension measurement. (a) Structure of S-TOP tip. (b) Micrograph of S-TOP.

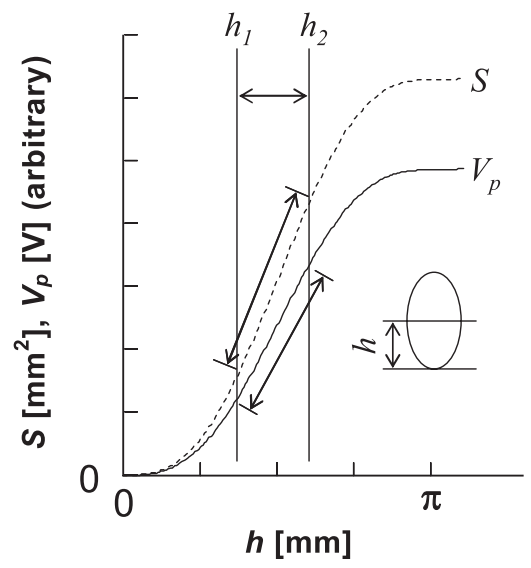

Fig. 4 Relation between covered area $S$ and photomultiplier output $V_{p}$. 
ここで，2aを棈円長軸長さ， $2 b$ を棈円短軸長さとする. また, 光電子増倍管で検出される戻り光量 (出力電圧信 号： $\left.V_{p}\right)$ はSに比例するため, 比例係数を $\beta$ とすると, $V_{p}$ とSの間には以下のような関係が成立する.

$$
V_{p} \propto \beta S
$$

さらに, Fig. 4に示すように，端面が覆われる高さを $h$ と すると, 区間 $h_{1}, h_{2}$ の出力信号には比例直線関係が成立 する。よって，その区間に沶ける気液界面速度を $U_{I}$, 気 液界面がその区間を通過する時間を $t$ とすると,

$$
h=U_{I} t
$$

となる。よって，以下の関係式が成立する。

$$
V_{p} \propto \beta S=\beta^{\prime} h=\lambda U_{I} t
$$

ここで, $\beta, \lambda$, $\lambda$ は比例係数である. つまり, 出力電圧 信号： $V_{p}$ と気液界面速度： $U_{I}$ の間には以下のような関係 式が成立し, 気泡・液滴の気液界面速度の算出が可能と なる。

$$
U_{I}=\alpha \frac{d V_{p}}{d t}
$$

さらに，次式を用いることで気泡・液滴の通過弦長 : $L$ の算出が可能となる.

$$
L=U_{I}\left(t_{2}-t_{1}\right)
$$

ただし， $t_{1}$ をプローブと気泡・液滴との接触開始時間, $t_{2}$ を接触終了時間とする。

本計測原理は, 液相表面張力により変化する光ファイ バ端面のぬれ性変化を利用したものである. 表面張力の 変化により，プローブ端面に沿って成長するメニスカス

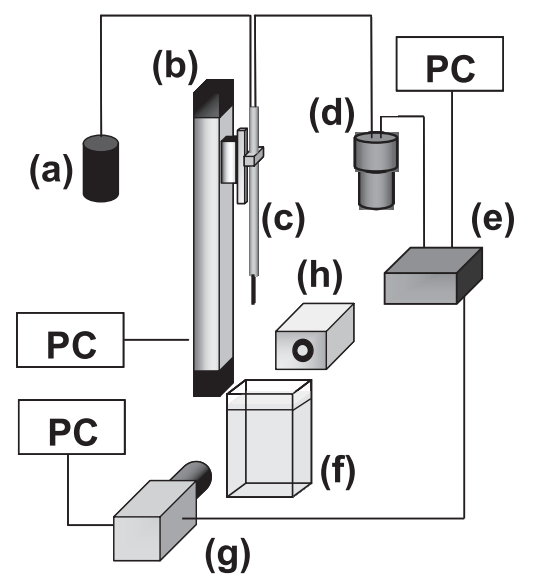

Fig. 5 Experimental setup. (a) Laser diode, (b) Servo actuator, (c) Single-tip optical fiber probe, (d) Photo multiplier, (e) A/D converter, (f) Acrylic water vessel, (g) High-speed video camera, (h) Halogen light source.
の速度が変化する．その際に生じる戻り光量の時間変化 率と表面張力との関係をまとめた校正曲線を用いること で，S-TOPによる表面張力を測定するものである。本研 究で開発したS-TOPによる表面張力測定技術により, 種々の工業分野で重要なパラメータである表面張力を, 従来とは全く異なる原理により簡易かつ高精度に測定す ることが可能となる。なお，端面角度は計測対象とする 気相 - 液相の屈折率から, 戻り光量変化 $($ 気相 - 液相 ベル值の差)が最大となる角度を採用している.

\section{3. 実験装置}

\section{1 実験装置及び方法}

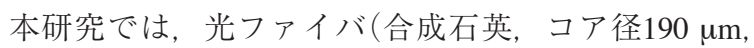
クラッド厚 $5 \mu \mathrm{m}$, ジャケット厚 $15 \mu \mathrm{m})$ の先端をマイク ロピペットベベラー (Sutter Instrument社製P-2000)を用い て $35^{\circ}$ の楔状に研磨し，注射針及びステンレスチューブ に挿入 · 固定したものを表面張力計測用S-TOP(以下, 単にS-TOP)として使用した(Fig. 3).

実験装置の概略をFig. 5に示す。実験装置は，PCによ り制御された精密自動ステージ (b)にS-TOP (c) を固定し, 気相から液相へと $100 \mu \mathrm{m} / \mathrm{s}$ の速度で移動させ, 気液界面 と接触させた。煮沸脱気したイオン交換水が満たされた アクリル製矩形水槽(f)に, 界面活性剂 (1-Pentanol)を0, $500,1,200,2,500,4,500,7,000,10,000,14,000$, $18,000 \mathrm{ppm}$ の濃度で添加し, 表面張力を変化させた。滴 重法により計測した各濃度における界面活性剂水溶液の 表面張力を, Table 1にまとめる。また, A/D変換器 (Sample rate: $1 \mathrm{MHz}$ ) (e) と同期させた高速ビデオカメラ (g) (Phantom V9, Samplerate: 4,000 fps, $3.0 \mu \mathrm{m} /$ pixel) を用 い, S-TOPと気液界面との接触過程を可視化撮影した。 なお，可視化光源にはハロゲンランプ(h) (出力 $200 \mathrm{~W}$ : 日星電気製)を使用した。

\section{2 信号処理}

表面張力計測における典型的な出力信号及び信号処理 の概略をFig. 6に示す. S-TOP信号を25点移動平均平滑

Table 1 Surface tensionin each -Pentanol concentration (at $20.1^{\circ} \mathrm{C}$ ).

\begin{tabular}{cc}
\hline $\begin{array}{c}\text { 1-Pentanol concentration } \\
{[\mathrm{ppm}]}\end{array}$ & $\begin{array}{c}\text { Surface tension } \\
{[\mathrm{mN} / \mathrm{m}]}\end{array}$ \\
\hline 0 & 75.7 \\
500 & 71.4 \\
1200 & 66.1 \\
2500 & 57.2 \\
4500 & 51.1 \\
7000 & 44.2 \\
10000 & 39.5 \\
14000 & 35.0 \\
18000 & 31.1 \\
\hline
\end{tabular}




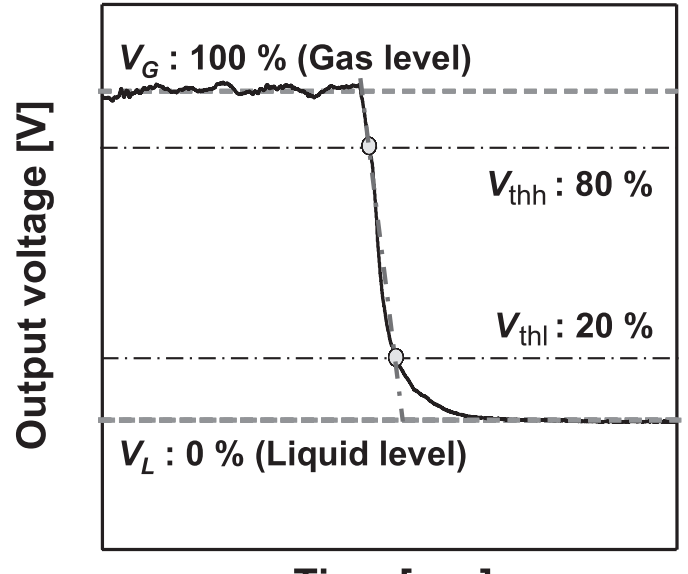

Time [sec]

Fig. 6 Processing of S-TOP signal.

化処理後, 出力電圧のヒストグラムを計算して液相レベ ル： $V_{L}$, ならびに気相レベル： $V_{G}$ を決定する ${ }^{18)}$. その液 相レベルを0\%, 気相レベルを100\%とし, 任意の二点 のしきい值： $V_{\mathrm{thl}}, V_{\mathrm{thh}}$ を定める。本実験においては, $V_{\text {thh }}: 80 \%, V_{\text {thl }}: 20 \%$ とした，この二点を結ぶ直線を信 号の傾きとし, 信号の立下り時の傾きを $g_{\text {rd }}$ とする. $g_{\text {rd }}$ は 次式により算出される。

$$
g_{\text {rd }}=\frac{\left(V_{\text {thh }}-V_{\text {thl }}\right)}{\Delta t} \frac{1}{\left(V_{G}-V_{L}\right)}
$$

この表面張力によって変化するメニスカスの成長速度を 特徵付ける $g_{\mathrm{rd}}$ と表面張力 $: \sigma$ との関係を, 種々の既知の 表面張力と温度下で求めて整理した後, 被測定対象液の 温度をパラメータとして，校正曲線を作成する。

\section{4. 結果と考察}

Fig. 7に表面張力の違いによる出力信号の変化を示す. 表面張力の減少に伴い, 出力信号の立ち下がり時の傾き が鋭くなっていることが分かる。 これは, 表面張力の低 下に伴い, S-TOPの材質である合成石英の臨界表面張力 が表面張力より小さくなるためである。固体と液体間の 狄性は, 固体の臨界表面張力と表面張力の大小関係で 決まる。本研究で取得した出力信号は, S-TOPと気液界 面の接触で生じる物理現象の変化(すなわち, 表面張力 の変化によるメニスカス成長速度の変化)を十分に捉え ていると考えられる。 さらに，Fig. 8に高速度ビデオカ メラによって可視化された気液界面挙動の相違を, 溶液 の表面張力をパラメータとして, $2 \mathrm{msec}$ 毎のスナップ ショットによって示す. 表面張力 $\sigma=75.7 \mathrm{mN} / \mathrm{m}$ (純水) の場合, S-TOPと気液界面の接触によるメニスカスの成 長速度が非常に遅い, 次に, 表面張力を減少させ $\sigma=$ $51.1 \mathrm{mN} / \mathrm{m}$ (1-Pentanol濃度4,500 ppm)に扔いては, $\sigma=$ $75.7 \mathrm{mN} / \mathrm{m}$ と比較してメニスカスの成長速度が増加して いる. $\sigma=31.1 \mathrm{mN} / \mathrm{m}$ (1-Pentanol濃度18,000 ppm)の場合, 接触開始から $4 \mathrm{msec}$ 後には, S-TOP端面が液相にほぼ完 全に覆われている。前述したようにS-TOPと気液界面と
の接触過程が表面張力の值に応じて変化し，Fig. 7に見 られるように出力の立ち下がり信号の傾きに変化が生じ ている。

Fig. 9にS-TOPからの出力信号の傾きと表面張力の関 倸(S-TOPによる表面張力測定に㧈ける校正曲線)を示す。 表面張力の減少に伴い, 出力信号の傾きが小さくなって いることが確認できる. 特に, $\sigma=60 \mathrm{mN} / \mathrm{m}$ 以下の範囲 では表面張力の減少に伴う $g_{\mathrm{rd}}$ の変化率が大きく, 高精度 な計測が可能な範囲である。 さらに, Table 2にS-TOPに よる表面張力計測に打ける不確かさをとりまとめる。こ の不確かさは, $66 \mathrm{mN} / \mathrm{m}$ 付近で最大になっている。こ の範囲に扔いては, 合成石英ファイバの臨界表面張力と 液相の表面張力の差が小さいために, メニスカス成長が 不安定であるためと考元られる。しかし， $g_{\text {rd }}$ の変化が大

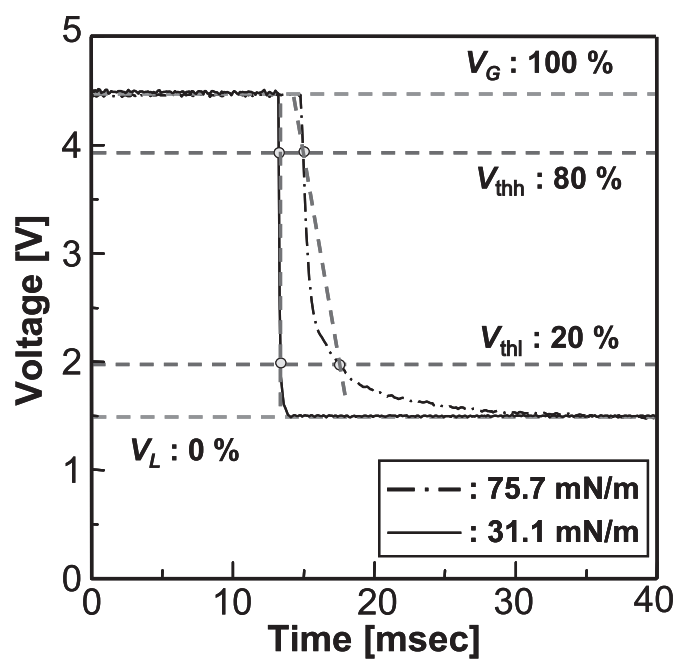

Fig. 7 Typical output voltage signals.
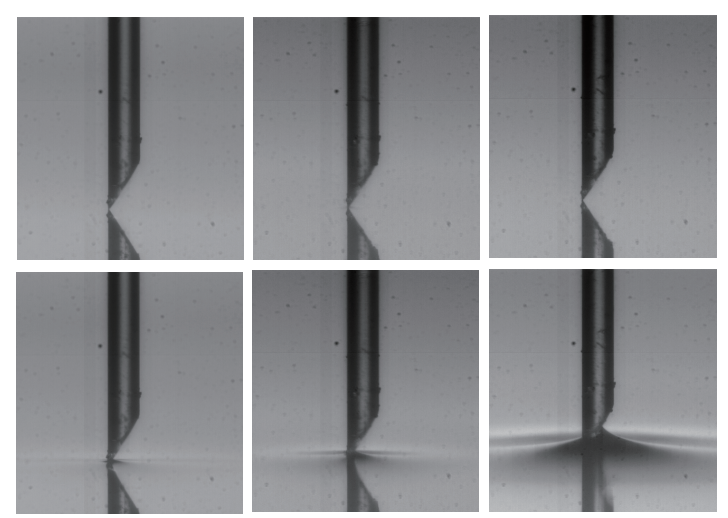

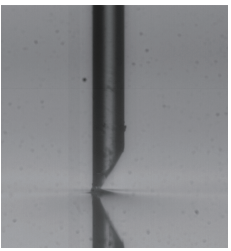

(a)

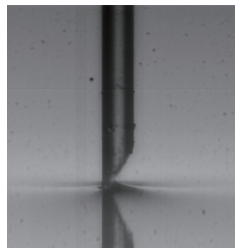

(b)

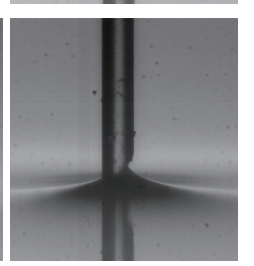

(c)
Fig. 8 Snapshots of gas-liquid interface behavior. (a) $\sigma=$ $75.7 \mathrm{mN} / \mathrm{m}$, (b) $\sigma=51.1 \mathrm{mN} / \mathrm{m}$, (c) $\sigma=31.1$ $\mathrm{mN} / \mathrm{m}$. 


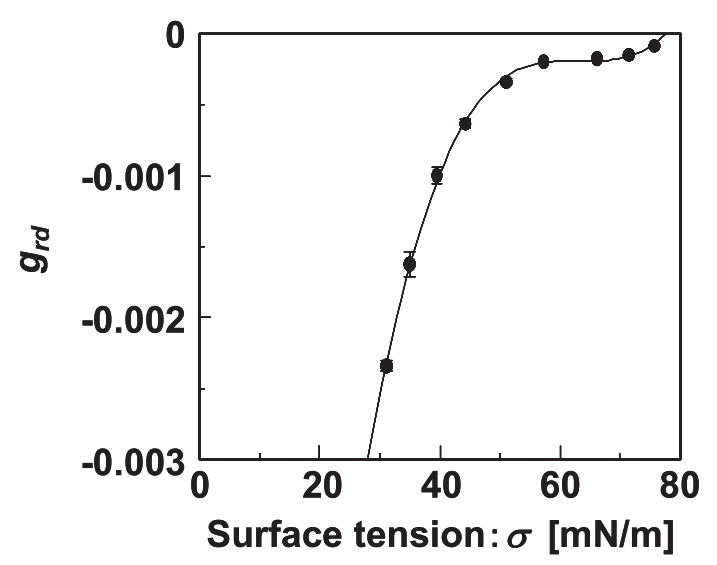

Fig. 9 Relationship between the grd of S-TOP signal and surface tension.

Table 2 Uncertainty in surface tension measurement using newly developed S-TOP.

\begin{tabular}{ccc}
\hline Surface tension $[\mathrm{mN} / \mathrm{m}]$ & Positive [\%] & Negative [\%] \\
\hline 75.7 & 4.2 & -4.5 \\
71.4 & 7.6 & -7.0 \\
66.1 & 10.9 & -9.7 \\
57.2 & 9.0 & -4.8 \\
51.1 & 5.7 & -6.3 \\
44.2 & 5.6 & -6.2 \\
39.5 & 6.0 & -4.0 \\
35.0 & 5.5 & -3.4 \\
31.1 & 1.6 & -1.8 \\
\hline
\end{tabular}

きい60 mN/m以下の範囲では, 計測の不確かさは減少し, 高精度な計測が可能である。また, S-TOPの出力信号の 不確かさを表面張力換算で考えた場合， $\sigma=35.0 \mathrm{mN} / \mathrm{m}$ で最大となるが, その值は5\%以下となり, 本計測手法 による表面張力測定の有効性が確認できたと考えられる.

\section{5. 結 言}

本研究では, 液相表面張力変化に伴うS-TOP (SingleTip Optical fiber Probe)のぬれ性変化を利用した表面張力 計測法を開発した。これにより，S-TOPを用いることで 気泡・液滴の径及び速度の計測に加え，工業技術におけ る重要なパラメータとなる表面張力を計測することが可 能となった。ささらに, 従来の光ファイバプローブによる 気泡・液滴特性のさらなる高精度計測が期待される。ま た，表面張力計測における不確かさは，表面張力換算で $5 \%$ 以内となり，高精度計測が可能であることを確認し た。

今後は，更に広範囲の液相表面張力に対応した校正曲 線を作成する。また，表面張力が既知の純物質を対象に 計測を行い，計測精度のさらなる検証を行う。

\section{参考文献}

1) A. Cartellier: Rev. Sci. Instrum. 61 (1990) 874.

2) A. Cartellier and J. L. Achard: Rev. Sci. Instrum. 62 (1991) 279.

3) A. Cartellier: Rev. Sci. Instrum. 63 (1992) 5442.

4) A. Cartellier: Nucl. Eng. Design 184 (1998) 393.

5) H. Moongeun, A. Cartellier, and J. E. Emil: Int. J. Multiphase Flow 30 (2004) 393

6) 齋藤：光ファイバープローブによる気泡計測方法及び装置 特許番号3018178 (2000).

7) R. F. Mudde and T. Saito: J. Fluid Mech. 437 (2001) 203.

8) T. Saito and R. F. Mudde: ICMF'01 (2001).

9) T. Saito, Y. Ishigaki, and Y. Mizuno: ICMF'04, Paper No.113 (2004).

10) 齋藤，北村，梶島，幡野：日本機会学会論文集 B 編 65 (1999) 2619.

11) 齋藤，梶島：日本機会学会論文集B編 68-674（2002）2719.

12) B. B. Sauer and W. G. Kampert: J. Colloid and Interface Science 199 (1998) 28.

13) S. Rebouillat, B. Steffenion, and B. Salvador: Chem. Eng. Sci. 57 (2002) 3953.

14) D. Seveno, G. Ogonowski, and J. De Coninck: Langmuir 20 (2004) 8385.

15) 齋藤, 真田, 小澤：界面物性測定装置及び方法 日本国特許 PCT/JP2008/54789.

16）小澤，齋藤他：レーザー学会学術講演会第28回年次大会 予稿集 (2008) 148.

17) T. Saito: ICMF'07, Paper No. KN9 (2007)

18) 坂本, 齋藤他：光ファイバーを利用した屈折率の異なる光 透過性流体の混相流動状態の計測方法および装置 特許出願 番号2005-037 501（2005）。 